\title{
Perception and Consumer Behavior of Halal Product Toward Purchase Decision in Indonesia
}

\author{
Much. Djunaidi *, Cut Baby Ayu Oktavia, Ratnanto Fitriadi, Eko Setiawan \\ Department of Industrial Engineering, Universitas Muhammadiyah Surakarta, Indonesia \\ Jl. Ahmad Yani, Pabelan, Kartasura, Sukoharjo, 57162, Indonesia \\ *Corresponding author: much.djunaidi@ums.ac.id
}

\section{ARTICLE INFO}

Article history

Received May 31, 2021

Revised August 18, 2021

Accepted August 19, 2021

Available Online August 31, 2021

Keywords

Halal

Consumer Perceptions

Consumer Behavior

Halal Products

Purchase Decision

\begin{abstract}
Indonesia is a country with a majority Muslim population. Therefore, Indonesian consumers have to be more thorough in assuring halal guarantees. One of some identities as a Muslim is consuming halal products. Various factors can affect consumers in purchasing halal products. However, the consumption of halalcertified products is still relatively low. This study was intended to analyze the factors that influenced consumer perceptions in purchasing halal products. A case study was carried out on the coffee product, one of Indonesia's most popular culinary products. The data were collected based on a survey of 170 respondents who live in Surakarta, Central Java Province, and are Muslim. This study suggested that the factors that significantly influenced the purchase were the variables of religiosity, halal label certification, and product prices. In contrast, the variables of halal awareness and brand image had no significant effect. Thus, the five variables simultaneously had a significant positive effect on purchasing decisions for halal products.
\end{abstract}

This is an open-access article under the CC-BY-SA license.

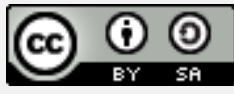

\section{Introduction}

Religion plays an essential role in life, including the aspect of food consumption. Food consumption affects individuals in following and implementing the rules and beliefs. Islam is a religion that regulates food matters. The food that is allowed is called halal product, and the food that is not allowed is called haram product. Halal in Islam emphasizes the concepts of safety, cleanliness, purity, and honesty in the manufacture, production, process, service of food, financial goods, and other social activities. Muslim consumers must ensure that the food they consume meets the halal requirements under Islamic law [1]. In 2020, the Muslim population in Indonesia was 229.12 million and was expected to increase. The Muslim population constitutes the majority of the population in Indonesia (87.2\%) and accounts for $13 \%$ of the world's Muslim population. Muslims currently account for about a quarter of the world's population. It is extraordinary market potential, so that the global halal market needs to be considered by producers [2]. Based on these facts, Indonesia is also a large potential market for consumer goods such as food, beverages, and medicinal products [3]. It is inseparable from the many basic needs 
required to meet daily needs. Therefore, food is a primary need that is always sought and continues to be needed. The food and beverage product development industry requires innovation and creativity, especially regarding product halalness. One of the products in the culinary field that is currently popular is coffee, especially among young people who certainly want to always be up to date in society. Some business people get around this by adding flavorings so that the coffee has a more delicious aroma and taste. This flavoring can be in the form of rum, nondairy creamer, flavor, or stabilizer, whose halal status is not yet clear [4]. To make Rum, molasses, or sugarcane juice is fermented before being distilled.

According to the Institute for the Study of Food, Drugs, Cosmetics, and Food, the Indonesian Ulama Council (LPPOM MUI), rum is classified into khamr (in Arabic). Khamr is a liquor produced from a mixture of various ingredients, and it is intoxicating. The prohibition against khamr is expressly stated in the Qur'an and Hadith. In the production process, a product's halalness is considered and protected by business actors and the government. Consumer behavior towards halal products is an essential part of the market assessment, which is vital to success in the halal industry [5]. An essential function of halal supply chain management is to ensure that the transformation process from raw materials to finished products is in the hands of consumers in halal conditions. It does not experience gray areas or haram conditions [6]. Purchase decisions for halal products are mostly associated with an individual or consumer behavior and perceptions. Amalia, et al. [7] explained that purchasing decisions are closely related to behavior, subjective norms, and perceived behavioral control. Some researchers have also agreed on other consumer perception factors, such as religiosity [8, 9]. Consumer concern for product halalness also influences purchasing decisions, as claimed by Awan, et al. [10], Nurhayati and Hendar [11], also by Gojali and Asih [12]. On the other hand, product purchase decisions are also associated with the condition of the product. Some references project the purchasing decisions with a mixed marketing strategy, including product, place, price, and promotion [13]. Widyastuti and Said examined product purchasing decisions regarding brand image, product design, and perception of price [14].

Unfortunately, some previous studies rarely investigated the influence of the halal aspects of products and consumer behavior towards purchasing decisions, especially in the coffee product in Indonesia. Therefore, this article discussed purchasing decisions for halal products from both sides, both from the consumer behavior and the halal certification of the coffee product. Several factors were chosen in the model based on the level of factor correlation to consumer purchasing decisions. Based on this description, this study intended to analyze the factors that influenced consumer behavior in purchasing halal products. The results could provide policies to increase consumer awareness in purchasing halal coffee in Indonesia. The contribution of this research is to enrich knowledge on the factors that influence purchasing decisions for halal products, especially coffee products in Indonesia.

\section{Methods}

The research implemented a quantitative analysis approach. The method for data analysis was multiple regression analysis. Multiple regression analysis was used to analyze the relationship between one dependent variable and many independent variables. In addition, the independent variables that influenced the dependent variable were investigated [15]. 


\subsection{Conceptual Framework}

Previous research was conducted to determine the factors that influenced consumer purchasing decisions. Several studies offered purchase decision factors that were different from other studies. This study was intended to combine various factors that influenced the purchase decision, especially for halal products. These factors include:

1. Halal Awareness (X1). Awareness in the context of halal means understanding what is good or what can be consumed and understanding what is wrong or should not be destroyed according to the rules in Islam, especially in the AlQuran and Hadiths [16].

2. Religiosity (X2). Religiosity contains values that require someone who believes in it to follow the applicable rules. Packaging food products with labels following specific religious rules can realize the regulations [17]. Consumers' choices are greatly influenced by their religion [18].

3. Brand Image (X3). The brand image represents the overall brand perception and is formed of information and experience of the product. A positive product image for a brand will make it more possible for consumers to make purchases.

4. Halal-Label Certification (X4). Halal certification is a fatwa from the Indonesian Ulema Council (MUI), which states the halalness of a product follows the Islamic law and is the primary basis for obtaining a permit to include a halal label on a product packaging from the authorized government in an area or region. In a featured product, the label is considered product information or description in images, writing, or a combination of both.

5. Product Prices (X5). Price is one of the factors in marketing stimuli that can influence consumer behavior. The price of a product can be a fairly important marketing tool because changes in the price of a product will result in changes in distribution and promotion channel policies.

6. Purchasing Decisions (Y). Purchasing decisions are choices made from several existing alternatives that have been developed and felt following the current conditions and the desired circumstances.

The framework regarding the relationship of variables is shown in Fig. 1. Meanwhile, the variables and indicators can be seen in Table 1. The initial hypothesis of this study is presented as follows: (1). Halal awareness has a positive influence on Purchasing Decisions; (2). Religiosity has a positive influence on Purchasing Decisions; (3). Brand Image has a positive influence on Purchasing Decisions; (4). Halal-Label Certification has a positive influence on Purchasing Decisions; and (5). Product Prices have a positive influence on Purchasing Decisions.

\subsection{Data Collection}

This study was conducted to examine the factors that influenced consumers of contemporary coffee products in making purchasing decisions, especially related to the coffee product's halalness. The research was conducted on contemporary coffee consumers who live around Surakarta, Central Java, Indonesia. Respondents were contemporary coffee connoisseurs who are Muslim and came from 5 well-known contemporary coffee shops in Surakarta, Central Java, Indonesia. Data collection on consumer perceptions of contemporary coffee was done using a questionnaire. Respondents' assessment of the questions was given in the form of a Likert scale, using 5 rating scales. The questionnaire 
was prepared on the Google Forms application, considering the Covid-19 pandemic, limiting respondents' direct questions.

Data collection was carried out from August to September 2020. Researchers asked coffee shop waiters to provide a questionnaire link to consumers who shopped during that time. In this way, data were obtained from 170 respondents. This study used parametric statistical analysis related to quantitative data. The questionnaire was tested by statistical data analysis with a minimum sample size of 30 respondents [19]. A validity test was used to determine the feasibility of items in the list of questions in defining a variable [20]. The technique to measure the validity of the questionnaire was the Product Moment correlation of Karl Pearson's [21]. A reliability test was conducted to measure the stability and consistency of respondents in answering questions related to the construct of the question [22].

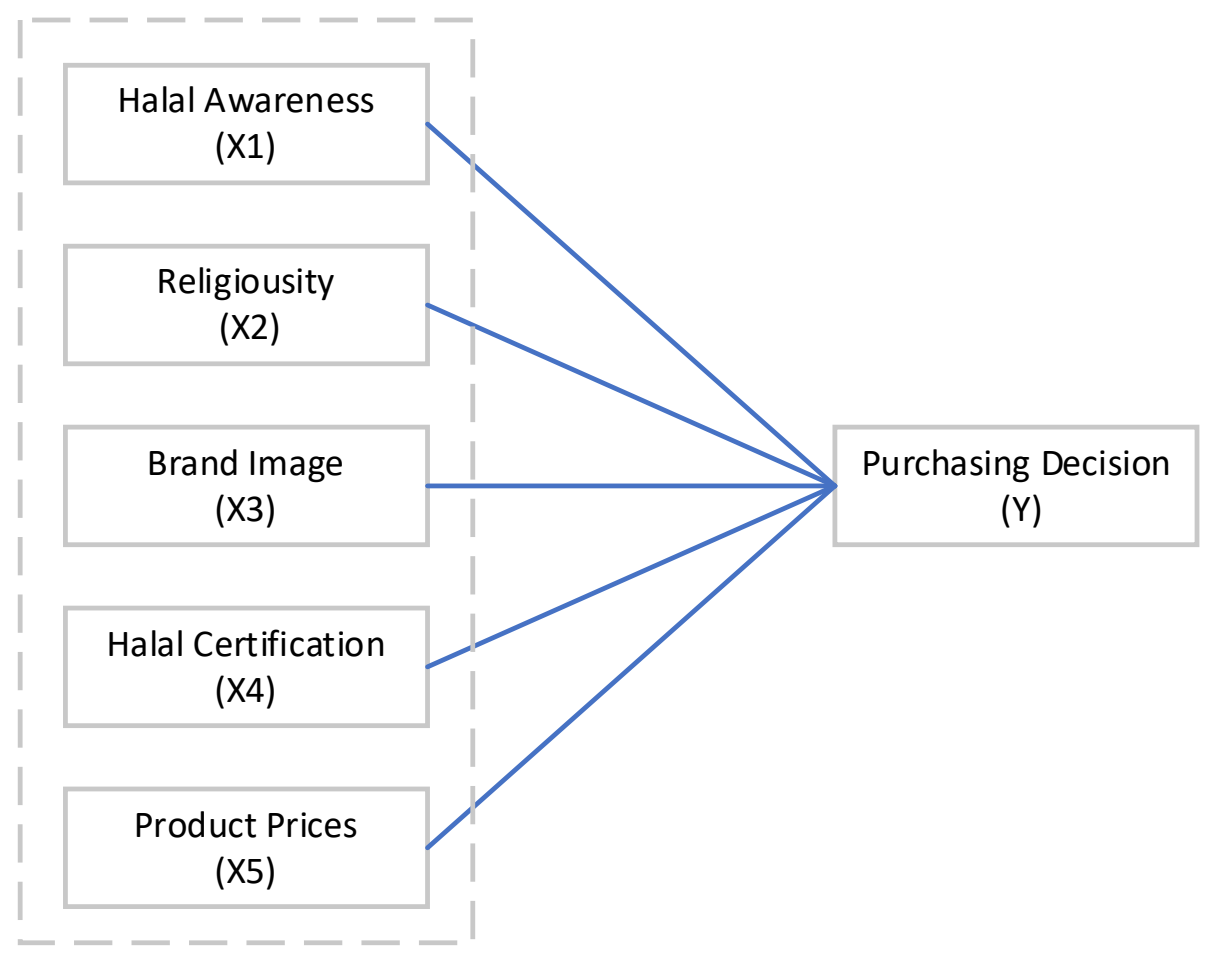

Fig. 1. The Relationship between Independent Variables and Dependent Variables

Next is the Classic Assumption Test, which used parametric statistics for data using an interval or ratio scale. This study also tested the classical assumptions such as normality, multicollinearity, and heteroscedasticity. The last stage was to perform a Multiple Linear Regression Test. Regression analysis estimated and predicted the mean value of the dependent variable based on the known value of the independent variable [23]. Finally, hypothesis testing was done by simultaneous testing (F test) and partial variable testing (t-test) [24].

\section{Results and Discussion}

\subsection{Analysis of Respondents' Characteristics}

The characteristics of the respondents are shown in Table 2. In this study, female respondents were almost twice that of male respondents. In addition, most of the 
respondents were young, between 21 to 25 years old (77.65\%), enjoyed coffee more than five times a month (75.29\%), and worked as students (66.47\%). This data displayed that most of the contemporary coffee connoisseurs were millennial youth groups.

Table 1. Variable and Indicators

\begin{tabular}{|c|c|}
\hline Variables & Indicators \\
\hline \multirow{5}{*}{ Halal Awareness (X1) [25] } & Avoiding syubhat (in Arabic) \\
\hline & Health assurance \\
\hline & Safety assurance \\
\hline & Information \\
\hline & Religious commitment \\
\hline \multirow{5}{*}{ Religiosity (X2) [26] } & Ideological beliefs \\
\hline & Religious practice \\
\hline & Consequences \\
\hline & Religious knowledge \\
\hline & Religious experience \\
\hline \multirow{5}{*}{$\begin{array}{l}\text { Brand Image (X3) } \\
{[27]}\end{array}$} & Popularity \\
\hline & Consumer orientation \\
\hline & Product credibility \\
\hline & Consumer orientation \\
\hline & Company credibility \\
\hline \multirow{5}{*}{$\begin{array}{l}\text { Halal-Label Certification (X4) } \\
\text { [28] }\end{array}$} & Experience \\
\hline & Knowledge \\
\hline & Understanding on product \\
\hline & Understanding on process \\
\hline & Confidence \\
\hline \multirow{5}{*}{$\begin{array}{l}\text { Product Prices (X5) } \\
{[29]}\end{array}$} & Product competitiveness \\
\hline & Compliance with quality \\
\hline & Compliance with ingredients \\
\hline & Brand competitiveness \\
\hline & Compatibility with benefits \\
\hline \multirow{7}{*}{$\begin{array}{l}\text { Purchasing Decisions (Y) } \\
\text { [30] }\end{array}$} & Product decisions \\
\hline & Seller decisions \\
\hline & Quality decisions \\
\hline & Brands decisions \\
\hline & Product decisions \\
\hline & Social decisions \\
\hline & Guarantee decisions \\
\hline
\end{tabular}


Table 2. Respondents' Characteristics

\begin{tabular}{|c|c|c|c|}
\hline Criteria & Characteristics & Frequency & $\%$ \\
\hline \multirow{3}{*}{ Gender } & Male & 62 & 36.47 \\
\hline & Women & 108 & 63.53 \\
\hline & Total & 170 & 100 \\
\hline \multirow{5}{*}{ Age } & $17-20$ & 25 & 14.71 \\
\hline & $21-25$ & 132 & 77.65 \\
\hline & $26-30$ & 7 & 4.12 \\
\hline & $31-35$ & 6 & 3.53 \\
\hline & Total & 170 & 100 \\
\hline \multirow{3}{*}{$\begin{array}{l}\text { Purchase } \\
\text { intensity in a } \\
\text { month }\end{array}$} & $3-5$ & 42 & 24.71 \\
\hline & $>5$ & 128 & 75.29 \\
\hline & Total & 170 & 100 \\
\hline \multirow{8}{*}{ Domicile } & Surakarta & 66 & 38.82 \\
\hline & Sukoharjo & 35 & 20.59 \\
\hline & Karanganyar & 25 & 14.71 \\
\hline & Boyolali & 15 & 8.82 \\
\hline & Klaten & 15 & 8.82 \\
\hline & Sragen & 9 & 5.29 \\
\hline & Wonogiri & 5 & 2.94 \\
\hline & Total & 170 & 100 \\
\hline \multirow{6}{*}{ Profession } & Student & 113 & 66.47 \\
\hline & Civil Servant & 1 & 0.59 \\
\hline & Private Employee & 19 & 11.18 \\
\hline & Entrepreneur & 8 & 4.71 \\
\hline & Others & 29 & 17.06 \\
\hline & Total & 170 & 100 \\
\hline
\end{tabular}

\subsection{Measure Test}

\subsubsection{Validity Test}

The validity test was carried out to measure the level of validity of the use of research instruments, namely the questions in the questionnaire. The results of the data validity test are shown in Table 3. Determination of the statement's validity was done by comparing the corrected item-total correlation value to the critical number $r$ in the table of product $r$ moment values at the significance value used. The results suggested that all the questions asked for each variable were declared valid.

\subsubsection{Reliability Test}

Reliability test measured the level of consistency for two or more measurements performed with the same symptoms with the same measuring instrument. The following are the results of the data reliability test, which can be seen in Table 4. Determining the reliability of a research instrument was conducted by Cronbach's alpha. The results obtained for the independent variable and its relationship were 0.887 (very strong). In 
contrast, the dependent variable had a value of 0.790 (strong). Thus, it could be stated that all question constructs had good reliability.

Table 3. Validity Test Results

\begin{tabular}{|c|c|c|c|}
\hline Variables & Indicators & R-Count & R-Table \\
\hline \multirow{5}{*}{$\begin{array}{l}\text { Halal Awareness } \\
{[25]}\end{array}$} & Avoiding syubhat & 0.533 & 0.150 \\
\hline & Health assurance & 0.561 & 0.150 \\
\hline & Safety assurance & 0.491 & 0.150 \\
\hline & Information & 0.520 & 0.150 \\
\hline & Religious commitment & 0.552 & 0.150 \\
\hline \multirow[t]{5}{*}{ Religiosity [26] } & Ideological beliefs & 0.511 & 0.150 \\
\hline & Religious practice & 0.542 & 0.150 \\
\hline & Consequences & 0.443 & 0.150 \\
\hline & Religious knowledge & 0.611 & 0.150 \\
\hline & Religious experience & 0.516 & 0.150 \\
\hline \multirow{5}{*}{$\begin{array}{l}\text { Brand Image } \\
\text { [27] }\end{array}$} & Popularity & 0.355 & 0.150 \\
\hline & Consumer orientation & 0.614 & 0.150 \\
\hline & Product credibility & 0.663 & 0.150 \\
\hline & Consumer orientation & 0.610 & 0.150 \\
\hline & Company credibility & 0.546 & 0.150 \\
\hline \multirow{5}{*}{$\begin{array}{l}\text { Halal-Label } \\
\text { Certification [28] }\end{array}$} & Experience & 0.609 & 0.150 \\
\hline & Knowledge & 0.686 & 0.150 \\
\hline & Understanding on product & 0.634 & 0.150 \\
\hline & Understanding on process & 0.463 & 0.150 \\
\hline & Confidence & 0.671 & 0.150 \\
\hline \multirow{5}{*}{$\begin{array}{l}\text { Product Prices } \\
\text { [29] }\end{array}$} & Product competitiveness & 0.168 & 0.150 \\
\hline & Compliance with quality & 0.579 & 0.150 \\
\hline & Compliance with ingredients & 0.560 & 0.150 \\
\hline & Brand competitiveness & 0.260 & 0.150 \\
\hline & Compatibility with benefits & 0.665 & 0.150 \\
\hline \multirow{7}{*}{$\begin{array}{l}\text { Purchasing } \\
\text { Decisions } \\
\text { [30] }\end{array}$} & Product decisions & 0.725 & 0.150 \\
\hline & Seller decisions & 0.595 & 0.150 \\
\hline & Quality decisions & 0.729 & 0.150 \\
\hline & Brands decisions & 0.643 & 0.150 \\
\hline & Product decisions & 0.615 & 0.150 \\
\hline & Social decisions & 0.699 & 0.150 \\
\hline & Guarantee decisions & 0.732 & 0.150 \\
\hline
\end{tabular}

Table 4. Reliability Test Results

\begin{tabular}{lll} 
Variables & Cronbach's Alpha & Std. Cronbach's Alpha \\
\hline Independent (X1, X2, X3, X4, X5 ) & 0.887 & 0.60 \\
Dependent (Y) & 0.790 & 0.60
\end{tabular}




\subsection{Model Interpretation and Multiple Linear Regression Equations}

Based on the results of data processing and multiple linear regression analysis carried out, the interpretation model and multiple linear regression equations were obtained, which are presented in Table 5.

Based on the classical assumption of normality test, the value of KolmogorovSmirnov Z was 1.187 with a value Asymp. Sig. (2-tailed) which showed a significance value of 0.119. It indicated that the residual results were normally distributed because the residual significance value was much greater than the significance value, namely alpha 0.05. Therefore, it could be concluded that the regression model was feasible because it met the assumptions and was normally distributed.

Based on the multicollinearity test, the Variance Inflation Factor (VIF) regression value was 1 . If the VIF value $<10$, the independent variable was multi-collinearity-free. The Collinearity Statistics section projected the tolerance and VIF values used to analyze the basis or decision making. It was known that the VIF value was $1<10$, so it could be concluded that there was no multicollinearity in the regression model.

The heteroscedasticity test with the Glejser Test was performed by regressing the absolute residual value on other independent variables. The results projected that the significance value obtained was 0.656 . Therefore, it could be concluded that the regression model was suitable for use because there was no heteroscedasticity or homogeneous data distribution.

Table 5. Multiple Linear Regression Model based on all variables

\begin{tabular}{lllll}
\hline Variables & $\mathrm{B}$ & T-Count & T-Table & Sig. \\
\hline $\mathrm{X} 1$ & 0.170 & 1.878 & 1.975 & .062 \\
\hline $\mathrm{X} 2$ & 0.246 & 2.951 & 1.975 & .004 \\
\hline $\mathrm{X} 3$ & -0.074 & -.971 & 1.975 & .333 \\
\hline $\mathrm{X} 4$ & 0.575 & 5.800 & 1.975 & .000 \\
\hline $\mathrm{X} 5$ & 0.305 & 4.400 & 1.975 & .000 \\
\hline
\end{tabular}

Table 6. Multiple Linear Regression Model based on significant variables

\begin{tabular}{lllll}
\hline Variables & Unst. B & Std. B & $t$ & Sig. \\
\hline (Constant) & 3.585 & & 2.256 & 0.008 \\
\hline X2 & 0.308 & 0.233 & 3.987 & 0.000 \\
\hline X4 & 0.567 & 0.443 & 6.775 & 0.000 \\
\hline X5 & 0.322 & 0.275 & 4.823 & 0.000 \\
\hline
\end{tabular}

Based on Table 6, the eliminated factors did not significantly influence the purchase decision. However, the retested variables indicated significant results at $\alpha=5 \%$, which could be seen from the significance probability value of 0.000 each. Thus, the purchasing decision variable (Y) was influenced by religiosity (X2), halal certification (X4), and product price (X5) with the following equation:

$$
\mathrm{Y} \quad=3.585+.308 \mathrm{X}_{2}+.567 \mathrm{X}_{4}+.322 \mathrm{X}_{5}+\mathrm{e}
$$


According to the analysis of the regression equation above, it could be explained that [31]. The coefficient of the constant $(\alpha=3.585)$ was positive. It showed that purchasing decisions would occur, even though there were no independent variables (halal awareness, religiosity, brand image, halal certification, and product prices).

The regression coefficient for Religion (X2) was positive. The Muslim community preferred to avoid drinking coffee that was not halal. It indicated that the Muslim community in the Surakarta area had religious beliefs and accepted the consequences as a religious observance. According to research conducted by Lutfia, religiosity had a positive effect on purchasing decisions. The higher a person's religiosity, the higher the decision to purchase halal products, and vice versa [32].

The regression coefficient for Halal Label Certification (X4) was positive. Consuming coffee beverage products with halal certification and labels made consumers felt protected. Research conducted by Marzuki et al. in a restaurant in Malaysia shows that halal certification had significant value affecting the commercial hospitality industry [33]. Thus, there was a significant relationship between willingness to pay for halal products and the demand for halal certification for food and other products [34].

The product price regression coefficient (X5) was positive. Consumers choose prices based on the guarantee and quality of the products consumed. Research conducted by Hidayat stated that the product price variable had a positive effect on purchasing decisions [35]. Trisnawan's research results also explained that consumer perceptions of product quality were often influenced by price, which impacted consumer purchasing decisions [36].

\subsection{Hypothesis Testing}

Based on F-test, the results of the simultaneous test or F-Test obtained that the F count of 55.956 was greater than the $\mathrm{F}$ table of 2.27 with a probability significance value of 0.000 smaller than the value of alpha 0.05 . So, it could be concluded that the regression coefficient of halal awareness, religiosity, brand image, halal certification, and product prices was not equal to zero, or it can be said that all independent variables simultaneously (together) had a significant effect on purchasing decisions (dependent variable). The results of hypothesis testing for the five independent variables on the dependent variable are presented in Table 5. The analysis of hypothesis testing on each variable was presented in the sub-section as follows:

\subsubsection{Halal Awareness on Purchasing Decisions}

The halal awareness variable with a significance value of 0.062 was declared insignificant because the value was $>0.05$ with a positive regression coefficient of 0.170 . This value suggested that the hypothesis that the halal awareness variable positively affected purchasing decisions was rejected. The factor of public halal awareness could be said to be low because consumer behavior in Indonesia was more driven by affective conditions (religiosity) than cognitive conditions (halal awareness) [37]. Muslim consumers need to be aware of the healthy, halal, and quality food and products they consume to ensure a healthy lifestyle and comply with the teachings and requirements of Islam [38]. Halal awareness positively influences product purchase decisions because consuming halal products is the obligation of Muslims. Therefore, people with high halal awareness would influence consumer purchasing decisions [39]. 


\subsubsection{Religiosity on Purchasing Decisions}

The religiosity variable with a significance value of 0.004 is declared significant because the value is $<0.05$ with a positive regression coefficient value of 0.246 . This value showed that the hypothesis that the variable religiosity had a positive effect on purchasing decisions was accepted. It was stated that the religious beliefs contained in a person could be taken into consideration. Religious beliefs influence consumers when choosing or consuming products [16].

\subsubsection{Brand Image on Purchasing Decisions}

The brand image variable with a significance value of 0.333 was declared insignificant because the value was $>0.05$ with a negative regression coefficient value of 0.074 . This value indicated that the hypothesis that the brand image variable positively affected purchasing decisions was rejected. Most respondents felt that the brand was not a consideration and their determination to buy coffee beverage products. This result showed that purchasing decisions were not only measured by-product image. Consumers were willing to pay more attention to product quality [40]. It is also supported by Shakil et al. [41], who explain that it is significant for business actors to guarantee halal characteristics. The execution of their goods or products is very important to improve the halal brand image.

\subsubsection{Halal-Label Certification on Purchasing Decisions}

The halal-label certification variable with a significance value of 0.000 was declared significant because its value was $<0.05$ with a positive regression coefficient of 0.575 . This value projected that the hypothesis that the halal-label certification variable positively affected purchasing decisions was accepted. This result was in line with the research conducted by Zakaria et al., which proved that a halal label on a product provided a positive value that had a great opportunity in making consumer decisions [42]. Shariff et al. said that halal certification guarantees all Muslim consumers following sharia provisions. In contrast, for non-Muslims, halal products are quality products based on halalan thoyyiban because they are integrated with GMP and HACCP [43].

\subsubsection{Product Prices on Purchasing Decisions}

The product price variable with a significance value of 0.000 was declared significant because the value was $<0.05$ with a positive regression coefficient value of 0.305. This value portrayed the acceptance of the hypothesis that the product price variable had a positive effect on purchasing decisions. In line with research conducted by Albari and Safitri, product prices positively impact purchasing decisions. It is because the price is one factor that influences consumer behavior in increasing purchasing decisions [44]

\section{Conclusion}

Based on the study results, the factors that influence consumer behavior towards purchasing halal products are jointly controlled by religiosity, halal certification, and product prices. Halal awareness and brand image factors did not affect consumer purchasing decisions. Not many respondents considered brand image in buying halal beverage products. The majority chose to agree that halal certification and labels needed 
to be included on packaging and outlets selling coffee beverage products. Manufacturers are urged to pay more attention and consider the interests of consumers. For further research, the investigation of indicators that affected each variable needed to be investigated. Therefore, the structural analysis of the equation model needs to be investigated further.

\section{Data Availability}

Raw data are not presented in the paper. If you need the raw data, please contact the author via email.

\section{Declarations}

Author contribution: All authors contributed equally to the main contributor to this paper. In addition, all authors read and approved the final paper.

Funding statement: This research did not receive any specific grant from funding agencies in the public, commercial, or not-for-profit sectors.

Conflict of interest: The authors declare that they have no conflicts of interest.

Additional information: No additional information is available for this paper.

\section{Acknowledgment}

The researcher would like to thank the Universitas Muhammadiyah Surakarta for supporting the research and extending the gratitude to the Industrial Optimization Laboratory for the help of facilities.

\section{References}

[1] S. G. Alqudsi, "Awareness and Demand for 100\% Halal Supply Chain Meat Products," Procedia - Social and Behavioral Sciences, vol. 130, pp. 167-178, 2014. https://doi.org/10.1016/j.sbspro.2014.04.021.

[2] S. Suleman, A. Sibghatullah, and M. Azam, "Religiosity, halal food consumption, and physical well-being: An extension of the TPB," Cogent Business \& Management, vol. 8, no. 1, p. 1860385, 2021. https://doi.org/10.1080/23311975.2020.1860385.

[3] I. Salehudin and B. A. Luthfi, "Marketing impact of halal labeling toward Indonesian muslim consumer's behavioral intention," vol. 3, pp. 35-44, 20112010. https://doi.org/10.21002/amj.v3i1.2013.

[4] B. Ahmad and M. K. Anwar, "Analisis Respon Pelaku Usaha Minuman Kopi (Coffee Shop) Terhadap Kewajiban Sertifikasi Halal," Jurnal Ekonomika dan Bisnis Islam, vol. 3, no. 2, 2020. https://journal.unesa.ac.id/index.php/jei/article/view/9222/4259.

[5] E. S. Soesilowati and C. I. Yuliana, "Komparasi Perilaku Konsumen Produk Halal di Area Mayoritas dan Minoritas Muslim," Jurnal Ekonomi dan Pembangunan, vol. 21, no. 2, pp. 167-178, 2013 2013. https://doi.org/10.14203/JEP.21.2.2013.49-60.

[6] M. Tieman, J. G. A. J. van der Vorst, and M. Che Ghazali, "Principles in halal supply chain management," Journal of Islamic Marketing, vol. 3, no. 3, pp. 217-243, 2012. https://doi.org/10.1108/17590831211259727.

[7] F. A. Amalia, A. Sosianika, and D. Suhartanto, "Indonesian Millennials' Halal food purchasing: merely a habit?," British Food Journal, vol. 122, no. 4, pp. 1185-1198, 2020. https://doi.org/10.1108/BFJ-10-2019-0748. 
[8] P. Garg and R. Joshi, "Purchase intention of "Halal" brands in India: the mediating effect of attitude," Journal of Islamic Marketing, vol. 9, no. 3, pp. 683-694, 2018. https://doi.org/10.1108/JIMA-11-2017-0125.

[9] A. Haque, N. Anwar, A. Tarofder, N. Ahmad, and S. Sharif, "Muslim consumers' purchase behavior towards halal cosmetic products in Malaysia," Management Science Letters, vol. 8, no. 12, pp. 1305-1318, 2018. http://doi.org/10.5267/j.msl.2018.9.009.

[10] H. M. Awan, A. N. Siddiquei, and Z. Haider, "Factors affecting Halal purchase intention - evidence from Pakistan's Halal food sector," Management Research Review, vol. 38, no. 6, pp. 640-660, 2015. https://doi.org/10.1108/MRR-01-2014-0022.

[11] T. Nurhayati and H. Hendar, "Personal intrinsic religiosity and product knowledge on halal product purchase intention," Journal of Islamic Marketing, vol. 11, no. 3, pp. 603-620, 2020. https://doi.org/10.1108/JIMA-11-2018-0220.

[12] D. Gojali and V. S. Asih, "Determinant factors of Indonesian muslim behavior in choosing halal products," Innovative Marketing, vol. 16, no. 4, p. 155, 2020. http://dx.doi.org/10.21511/im.16(4).2020.14.

[13] A. N. Widyastuti, P. Pujiharto, N. Tubastuvi, and S. B. Santoso, "The Effect of Marketing Mix on Purchase Decisions," Jurnal Manajemen Bisnis, vol. 11, no. 2, pp. 163-176, 2020. https://doi.org/10.18196/mb.11295.

[14] S. Widyastuti and M. Said, "Consumer consideration in purchase decision of SPECS sports shoes product through brand image, product design and price perception," International Journal of Supply Chain Management, vol. 6, no. 4, pp. 199-207, 2017.

[15] G. K. Uyanık and N. Güler, "A Study on Multiple Linear Regression Analysis," Procedia - Social and Behavioral Sciences, vol. 106, pp. 234-240, 2013. https://doi.org/10.1016/j.sbspro.2013.12.027.

[16] T. R. Pramintasari and I. Fatmawati, "Pengaruh Keyakinan Religius, Peran Sertifikasi Halal, Paparan Informasi, dan Alasan Kesehatan Terhadap Kesadaran Masyarakat Pada Produk Makanan Halal," Jurnal Manajemen Bisnis, vol. 8, no. 1, pp. 1-33, 2017. https://journal.umy.ac.id/index.php/mb/article/view/3922.

[17] L. Schiffman and L. J. I. Kanuk, Upper Saddle River, New Jersey, "Consumer Behavior Practice-Hall International," 2010.

[18] M. Said, F. Hassan, R. Musa, and N. A. Rahman, "Assessing Consumers' Perception, Knowledge and Religiosity on Malaysia's Halal Food Products," Procedia - Social and Behavioral Sciences, vol. 130, pp. $120-128, \quad 2014$. https://doi.org/10.1016/j.sbspro.2014.04.015.

[19] A. Lestari, "Pengaruh kepemimpinan partisipatif dan komitmen organisasi terhadap efektifitas implementasi rencana stratejik pada madrasah aliyah di kabupaten sukabumi jawa barat," Jurnal Administrasi Pendidikan, vol. 23, no. 1, 2016. https://doi.org/10.17509/jap.v23i1.

[20] V. W. Sujarweni, "Metode penelitian: Lengkap, praktis, dan mudah dipahami," ed: Yogyakarta: Pustaka baru press, 2014.

[21] F. Jowhari, W. M. Hopman, and L. Hookey, "A simple ergonomic measure reduces fluoroscopy time during ERCP: A multivariate analysis," Endoscopy international open, vol. 5, no. 03, pp. E172-E178, 2017. http://doi.org/10.1055/s-0043-102934.

[22] A. Tommasetti, R. Mussari, G. Maione, and D. Sorrentino, "Sustainability Accounting and Reporting in the Public Sector: Towards Public Value Co-Creation?," Sustainability, vol. 12, no. 5, 2020. http://doi.org/10.3390/su12051909.

[23] J. Araiza-Aguilar, M. Rojas-Valencia, R. Aguilar-Vera, and Management, "Forecast generation model of municipal solid waste using multiple linear regression," Global 
Journal of Environmental Science, vol. 6, no. 1, pp. 1-14, 2020. https://doi.org/10.22034/GJESM.2020.01.01.

[24] B. Bittman, A. Davies, W. Russell, and E. Goussakova, "Advance Placement and the achievement gap in the 21st century: A multiple linear regression of marginalized populations in AP enrollment," Research in Social Sciences Technology, vol. 2, no. 2, 2017. https://doi.org/10.46303/ressat.02.02.2.

[25] Y. A. Aziz and N. V. Chok, "The Role of Halal Awareness, Halal Certification, and Marketing Components in Determining Halal Purchase Intention Among NonMuslims in Malaysia: A Structural Equation Modeling Approach," Journal of International Food \& Agribusiness Marketing, vol. 25, no. 1, pp. 1-23, 2013. https://doi.org/10.1080/08974438.2013.723997.

[26] M. Djunaidi, C. B. A. Oktavia, R. Fitriadi, and E. Setiawan, "Perception and Consumer Behavior of Halal Product Toward Purchase Decision in Indonesia," Jurnal Teknik Industri, vol. 22, no. 2, 2021. http://dx.doi.org/10.6007/IJARPED/v6i3/3176.

[27] R. Gambetti, S. Biraghi, D. E. Schultz, and G. Graffigna, "Brand wars: consumerbrand engagement beyond client-agency fights," Journal of Strategic Marketing, vol. 24, no. 2, pp. 90-103, 2016. https://doi.org/10.1080/0965254X.2015.1011199.

[28] N. A. Salindal, "Halal certification compliance and its effects on companies' innovative and market performance," Journal of Islamic Marketing, vol. 10, no. 2, pp. 589-605, 2019. https://doi.org/10.1108/JIMA-04-2018-0080.

[29] A. T. Vogel and K. Watchravesringkan, "Consumer evaluations of trend imitation: brand equity, consumer attitudes and preference," Journal of Product \& Brand Management, vol. 26, no. 5, pp. 516-527, 2017. https://doi.org/10.1108/JPBM-072016-1257.

[30] Q. Ayuniyyah, D. Hafidhuddin, and H. Hambari, "Factors affecting consumers' decision in purchasing MUI halal-certified food products," Tazkia Islamic Finance Business Review, vol. 10, no. 2, 2017. http://dx.doi.org/10.30993/tifbr.v10i2.111.

[31] K. Patel, A. Mohamed, and G. W. van Vuuren, "A regression and comparative study of United States and South African yield curves using principal component analysis," South African Journal of Economic Management Sciences, vol. 21, no. 1, pp. 1-15, 2018. https://doi.org/10.4102/sajems.v21i1.1626.

[32] A. Ali, G. Xiaoling, M. Sherwani, and A. Ali, "Antecedents of consumers' Halal brand purchase intention: an integrated approach," Management Decision, vol. 56, no. 4, pp. 715-735, 2018. https://doi.org/10.1108/MD-11-2016-0785.

[33] A. Abror, D. Patrisia, Y. Engriani, S. Evanita, Y. Yasri, and S. Dastgir, "Service quality, religiosity, customer satisfaction, customer engagement and Islamic bank's customer loyalty," Journal of Islamic Marketing, vol. 11, no. 6, pp. 1691-1705, 2020. https://doi.org/10.1108/JIMA-03-2019-0044.

[34] W. Ahmed, A. Najmi, H. M. Faizan, and S. Ahmed, "Consumer behaviour towards willingness to pay for Halal products," British Food Journal, vol. 121, no. 2, pp. 492 504, 2019. https://doi.org/10.1108/BFJ-02-2018-0085.

[35] E. Grace, R. M. Girsang, S. Simatupang, V. Candra, and N. Sidabutar, "Product Quality And Customer Satisfaction And Their Effect On Consumer Loyalty," International Journal of Social Science, vol. 1, no. 2, pp. 69-78, 2021. https://doi.org/10.53625/ijss.v1i2.138.

[36] I. Razak, N. Nirwanto, and B. Triatmanto, "The impact of product quality and price on customer satisfaction with the mediator of customer value," IISTE: Journal of Marketing Consumer Research, vol. 30, pp. 59-68, 2016. https://iiste.org/Journals/index.php/JMCR/article/vi. 
[37] F. O. Fatmi, A. N. Ahmad, and B. Kartika, "Determinants affecting purchase intention of halal products: an article review," Journal of Halal Product Research, vol. 3, no. 2, pp. 63-79, 2020. http://dx.doi.org/10.20473/jhpr.vol.3-issue.2.63-79.

[38] Y. Sulaiman, N. K. N. Mat, and N. H. Abd Ghani, "' "The Antecedents of Halal Consumption Pattern: The Mediating Role of Muslim Lifestyle, Risk Perception and Trust"," International Journal of Engineering Technology, vol. 7, no. 4.38, pp. 10061011, 2008. http://dx.doi.org/10.14419/ijet.v7i4.38.27627.

[39] E. D. Setyaningsih and S. Marwansyah, "The effect of halal certification and halal awareness through interest in decisions on buying halal food products," Syiar Iqtishadi: Journal of Islamic Economics, Finance Banking, vol. 3, no. 1, pp. 65-79, 2019. http://dx.doi.org/10.35448/jiec.v3i1.5515.

[40] Y. Zhang, "The impact of brand image on consumer behavior: A literature review," Open journal of business management, vol. 3, no. 01, p. 58, 2015. http://doi.org/10.4236/ojbm.2015.31006.

[41] S. Shakil and S. Majeed, "Brand purchase intention and brand purchase behavior in halal meat brand," Journal of marketing, vol. 152, pp. 164-182, 2018. https://ideas.repec.org/a/ksb/jourml/v1y2018p163-182.html.

[42] Z. Zakaria, M. A. Majid, Z. Ahmad, Z. Jusoh, and N. J. J. o. F. Zakaria, "Influence of Halal certification on customers' purchase intention," Journal of Fundamental Applied Sciences, vol. 9, no. 5S, pp. 772-787, 2017. http://doi.org/10.4314/jfas.v9i5s.55.

[43] S. M. Shariff and N. A. A. Lah, "Halal Certification on Chocolate Products: A Case Study," Procedia - Social and Behavioral Sciences, vol. 121, pp. 104-112, 2014. https://doi.org/10.1016/j.sbspro.2014.01.1112.

[44] I. Safitri, "The Influence of Product Price on Consumers' Purchasing Decisions," Review of Integrative Business Economics Research, vol. 7, pp. 328-337, 2018. 